\title{
Action Research on Improving Female Participation in Cooperative Learning: In Case of Biology Department, Bule Hora University
}

\author{
Million Chimdessa, Aman Wako \\ Biology Department, Bule Hora University, Bule Hora, Ethiopia \\ Email address: \\ millionchmd@gmail.com (M. Chimdessa),amexwako@gmail.com (A. Wako)
}

\section{To cite this article:}

Million Chimdessa, Aman Wako. Action Research on Improving Female Participation in Cooperative Learning: In Case of Biology

Department, Bule Hora University. International Journal of Education, Culture and Society. Vol. 5, No. 6, 2020, pp. 120-125.

doi: $10.11648 /$ j.ijecs.20200506.12

Received: August 28, 2020; Accepted: September 19, 2020; Published: November 11, 2020

\begin{abstract}
Education is one of the social factors where by gender inconsistency is reflected. Cooperative learning is an approach to team work that reduces the occurrence of those unpleasant situations and exploits the learning and satisfaction that result from working on a high-performance team. The proven benefits of cooperative learning notwithstanding, instructors who attempt it frequently encounter resistance and sometimes open hostility from the students and create conducive environments for students to release ideas freely and interact with each other. Although the change of government policies in Ethiopia improves female participation in education, participation of female students are not as much satisfactory, especially in cooperative learning system and dependent rate of female students on male active learners are clearly known. Therefore, the major purpose of this action research is to improve female students' participation in cooperative learning system in order to create conducive learning environment and to enhance the academic performance of female students through cooperative learning in case of Bule Hora University, Department of Biology. The random sampling techniques was used to select respondent from first year to third year female students, out of all groups of one to five in all class of Biology Department College of Natural and Computational science in Bule Hora University. The total of thirty one female students from one to five group participant was selected from all years of each groups, and one female students were randomly selected to fill the questions. Based on the assessment of this action research, $100 \%$ of the females were participated in group working activities. The activities of the females participation in group work is different, which is valued as $41.9 \%, 38.7 \%, 12.9 \%$ and $6.5 \%$ always, sometimes, rarely and usually respectively respond as their work in group assignment by asking question to be answered by group members.
\end{abstract}

Keywords: Cooperative Learning, Group Work, Females, Students

\section{Introduction}

Learning is generally defined as cognitive change, that is, some addition to a learner's knowledge structures or reorganization and reconstruction of that learner's existing knowledge. This change occurs as connections is made between new material and prior knowledge and then integrated into the learner's existing knowledge base. In group learning, students are divided into small groups to learn content knowledge, to explore or discuss an assigned topic, or to complete cases, projects and group assignments, to answer a few challenging questions, or teenage in an exchange of ideas, and share some insights with group members $[1,2]$.

Cooperative learning is described as teaching method in which students work together in small groups to help one another learn academic content [3]. It is believed to provide a more comfortable and supportive learning environment than solitary work $[4,5]$.

According to socio-cognitive learning theory $[6,7]$ cognitive change is strongly influenced by interaction and activity with others. Because of this reason, today various College and university students are increasingly being facilitated to work co-operatively and learn collaboratively. This increased emphasis on group learning is partly a reaction 
to societal changes including a new emphasis on team work in the business sector coupled with a realization that in a rapidly changing information society communication skill are increasingly important [8].

At the tertiary level of education, the reasons include an increasingly diverse student population who need to develop ways of learning together in order to achieve, the increased use of teaching and learning that emphasize learner-driven approaches such as peer learning [9].

Researchers have shown that group learning leads to academic and cognitive benefits. [10] Reported that, Group learning promotes student learning and achievement increase the development of critical thinking skills, and promote greater transfer of learning. Group learning also aids in the development of social skills such as communication, presentation, problem solving, leadership, delegation and organization [9]. Constructivism fosters active learning over passive learning, collaboration over competition, and community over isolation $[11,12]$. It is featured by small group work.

These days, Ethiopian community schools starting from primary level to higher institution are implementing cooperative learning in the name locally called 'one-to-five' organization even though the implementation is at its infant stage. The method was implemented with the objective of enhancing students' educational achievements in particular and improving quality of education in general.

Education is one of the social factors where by gender disparity is reflected. In the field of education, the number of educated females is very low compared to male students. As the grade level in school increases, the number of female students starts to decline because of lots of factors such as religious ideology, culture, sexual harassment and earlier marriage. Consequently, higher education remains an area of learning from which females are less represented both as a student and staff. The New Education and Training Policy of Ethiopia in 1994 start the strategies used to increase females' participation in all levels of education.

Although Ethiopia's education and training policy stresses the need to sensitize society about the importance of girls' education, it has nevertheless a long way to go in making its dream to become true.

\subsection{Statement of the Problem}

Cooperative work is a group work that minimizes the occurrence of those unpleasant situations and maximizes the learning and satisfaction that result from working on a high-performance team. According to Weimer [13] the most common teaching method commonly employ in college professors reported that lecture was their "primary approach" to teaching, and Cooperative Learning is not common practice. Teaching learnig method is Relative instructor-centered lectures, individual assignments.

According to Menges, R. J. and Weimer, M. [14], many educators are using active learning pedagogies, such as cooperative or team-based learning.

Another reason for a lack of either interest or success with cooperative learning is that it can be problematic and teachers have worried over the ability to effectively assess pupils as individuals when they work in their Cooperative Learning and group leaders not give the chance [15]. Lack of clear objectives, lack of choice and flexibility, difficulty in accommodating cultural and language differences by students and collaboration are some of the factors which affect using Cooperative learning in classroom teaching [16].

This action research tries to find effective implementation of cooperative learning and participation of female students in group working. Female education is recognizing as one of the critical path way to promote social and economic development as well as a means to enhance women's in development efforts effectively and meaningfully. Evidence in Ethiopia indicate that's due to some change in government policies there have been improvements in female participation in education, however, the participation of female students are not as much satisfactory especially in cooperative learning system and dependent rate of female students on male active learners are clearly known in this generation.

Therefore, the major purpose of this action research is to improve female students' participation in cooperative learning system in order to facilitate better learning environment and to enhance the academic performance of female students through cooperative learning in case of Bule Hora University Department of Biology.

The following basic questions was designed to investigate the problems and made proper intervention for improvement of female students' participation in cooperative learning for better achievement; this action research project was answers the following basic questions:

1. What is the status of female students' participation in cooperative learning?

2. How can we improve female students' achievement through cooperative learning?

3. What are the factors contributing to low participation of female students' in cooperative learning?

4. What are the possible strategies that help to improves participation of female students' in cooperative learning?

\subsection{Objectives of the Study}

\subsubsection{General Objective}

The general objective of this action research is to determine participation of female students in cooperative learning system.

\subsubsection{Specific Objectives}

1. To Improve participation of female students in cooperative learning

2. To improve achievement of female students through the application of cooperative learning

3. To reduce the major challenges that hinders the participation of female students in cooperative learning

4. To apply possible strategies that help to facilitate participation of female students in cooperative learning 


\section{Research Design and Methodology}

\subsection{Study Area}

This study was conducted in Bule Hora University College of natural Science Department Biology $1 \mathrm{st}, 2^{\text {nd }}$ and $3^{\text {rd }}$ year female students in the 2017 academic year. Bule Hora University is among third phase newly established ten university of Ethiopia. It started formal teaching learning activities in 2012 by accepting two hundred fifty students within two faculties. Currently, the university is teaching more than six thousand students in regular and weekend programs in six faculties and thirty three departments. Biology department is among the departments under College of natural and computational science.

\subsection{Study Design}

Both qualitative and quantitative research methods were used. A qualitative research approach had been applied, using semi-structured questionnaires interviews. Cross-sectional study was used to assess factors affecting the participation of female students in group work and activities in class room teaching in cooperative learning process from February to June 2017 in Biology departments.

\subsection{Sampling Size and Sampling Technique}

From first year to third year students of Biology Department College of Natural and Computational science were sampled using simple random sampling techniques out of all groups of one to five in all class.

Then, total 31 female students from one to five group participant were selected by simple random sampling. There are seven groups of one to five in third year, eight groups in second year and eight group in first year students, having section 1 and II, each of with eight group and from all years of each groups, one female students were randomly selected to fill the questions

\subsection{Data Collection Tools}

In this study, the instruments such as questionnaires, and focus group discussion were applied. The questioner was distributed and filled by female students from one to- five organizations, and the researchers was select one female students from each group of one to five organization through $1^{\text {st }}, 2^{\text {nd }}$ and $3^{\text {rd }}$ year female students from biology department.

\subsection{Data Analysis}

Data collected using questionnaires had been analyzed using SPSS version 20.00 computer software by using descriptive statistics such as frequency, and mean for questionnaires and presented in tables, statements and interpreted quantitatively and qualitatively. In addition, data that had been taken by focus group discussion using questionnaires as checklist were interpreted qualitatively and presented in a summarized form.

\section{Data Analysis and Interpretation}

This heading presents the analysis and interpretation of the data which were collected through questionnaires, and focus group discussion. The heading has two main sections. The first section deals with the analysis and interpretation of the data which were collected through questionnaires; the second section presents results of data obtained from focus group discussion.

The total of 31 copies of questionnaires were distributed to 31 students and filled out properly and returned back. The results of the students' responses to the questionnaires is tabulated and analyzed as follows. The study was focused on participation of female in cooperative working such as assignment working, group discussion in class, etc. To study the activity of female's students on group assignment and group discussion, we prepare the following question. About $93.5 \%$ of the total female students responded as the instructor giving group work Assignment during their teaching. From this total females students $35 \%$, almost all, $41.9 \%$ some, $16.1 \%$ very few instructor use group work in class room teaching. About 6.5\% of the teachers not used group work in class due to lack of time to cover the portion based on the student response. About $71 \%$, $19.4 \%$ and $59.7 \%$ of the students reported that, group work is given sometimes, always and rarely respectively.

\subsection{Participation of Females in Group Work Assignment}

Based on the assessment of this action research, $100 \%$ of the females were participated in group working assignment. The activities of the females participation in group work is different $41.9 \%, 38.7 \%, 12.9 \%$ and $6.5 \%$ always, sometimes, rarely and usually respectively respond as their work in group assignment by asking question to be answered by group members. From female students, about 58.1\% always, $22.6 \%$ sometimes, $16.1 \%$ usually and $3.2 \%$ rarely participated in group working assignment by giving answer for question which given by teachers.

\subsection{Participation of Female in Group Discussion in Class Room}

The study shows that, about $54.8 \%$ always, and $22.6 \%$ sometimes of the female students were answered for the question how they actively participated in group discussion in the class. From the total respondents, $54.8 \%$ of female students always write report of group discussion. About, $12.9 \%$ usually, $22.6 \%$ sometimes and $9.7 \%$ rarely participated in report writing during group discussion.

\subsection{The Advantage of Cooperative Working During Group Discussion}

This action research supports our initial thoughts that there is a direct correlation between low ability students and the effectiveness of cooperative learning. One area we improve in this action research is increase the participation of female students in making actively involved in the cooperative learning process. One specific area of this research finding is 
that organizational skills effect how low ability of female students perceives cooperative learning. Based on the importance of cooperative learning, $58.1 \%$ always, $19.4 \%$ sometimes, $12.9 \%$ usually and $9.7 \%$ rarely of female students agree as we learn better from cooperative work than lecture from the instructor during group discussion. About 22.6\% always and $22.6 \%$ usually reported as one of the main problems of cooperative learning is group members do not respect everyone's opinion but about $32.3 \%$ never, $16.1 \%$ rarely and $6.5 \%$ sometimes respond to this idea. Some problem which decrease the active participation of female in group working was includes lack of interest to participate in group work, Some members get good grade without doing group work, Group members share roles such as leader, secretary, presenter and etc, Group assignment is done by one student, Some group members forget to do their share work and Some members do not share works equally (Table 1)

Table 1. The activity of female students in cooperative learning.

\begin{tabular}{|c|c|c|c|c|c|}
\hline \multirow{2}{*}{ Factors } & \multicolumn{5}{|c|}{ Variable used to give answer } \\
\hline & Never & Rarely & Sometimes & Usually & Always \\
\hline Some members do not participate & 35.5 & 29.0 & 9.7 & 6.5 & 19.4 \\
\hline Some members get good grade without doing work & 38.7 & 3.2 & 9.7 & 22.6 & 25.8 \\
\hline Group members share roles such as leader, secretary, presenter and etc. & 3.2 & 3.2 & 25.8 & 9.7 & 58.1 \\
\hline $\begin{array}{l}\text { Group members share activities like collection, evaluation, and } \\
\text { organization of evidences from various sources }\end{array}$ & - & 9.7 & 22.6 & - & 67.7 \\
\hline Group assignment is done by one student & 22.6 & 12.9 & 12.9 & - & 51.6 \\
\hline Some members do not share works equally & 32.3 & 22.6 & 25.8 & - & 19.4 \\
\hline
\end{tabular}

\subsection{The Problem That Hinder Participation of Female Students in Group Work}

In this action research, many questions are raised to identify the problem that influences the participation of female in group working in cooperative learning system. About 25.8\% agree and $16.1 \%$ strongly agree on lack of follow up and encouragement from the concerned body as factor contributed to this failure. But, about $35.5 \%$ disagree and $22.6 \%$ strongly disagree on the questions regarding lack of follow up and encouragement from the concerned body not influence the participation of female in group work. The next question as the factors which influence participation of female in group work of cooperative learning was Behavior of friends (peer pressure). On this issue, about $22.6 \%$ agree and $3.2 \%$ of female students strongly disagree peer as the pressure may cause the participation of female in group work. About $25.8 \%$ strongly disagree, 35.5 disagree and $12.9 \%$ undecided on these ideas as a factors.

About $51.6 \%$ disagree and 22.6 strongly disagree on the ideas your leader is not giving opportunity to participate as one factor. Only about, $12.9 \%$ agree and $9.7 \%$ strongly agree on your leader is not giving opportunity to participate is one of the factor which influence the participation of female students in group work.

About, $41.9 \%$ disagree and 38.7 strongly disagree on the idea of leader's unwillingness to involve the female to participate in group working assignment. In another case, 9.7\% undecided, $6.5 \%$ agree and 3.2 strongly agree on the ideas of leader's unwillingness to involve as one problem of hindering the participation of female in group working assignment. Other Factors which affecting participation of female students in cooperative learning in group work is willingness to participate, the grouping method is not inclusive, because of one member dominate the participation, lack of educational material(s) and other resources, the communication language during the discussion being in English/language barrier/ and being dependent on few respondents during discussion were some factors which affect the participation of female in group work (Table 2)

Table 2. Factors affecting the participation of female students in cooperative learning

\begin{tabular}{|c|c|c|c|c|c|}
\hline \multirow[b]{2}{*}{ Factors affecting female students participation in group work } & \multicolumn{5}{|l|}{ Variables } \\
\hline & $\begin{array}{l}\text { Strongly } \\
\text { disagree }\end{array}$ & Disagree & Undecided & Agree & $\begin{array}{l}\text { Strongly } \\
\text { agree }\end{array}$ \\
\hline Your groups are not willing to participate & 32.3 & 38.7 & 9.7 & 3.2 & 16.1 \\
\hline The grouping method is not inclusive & 22.6 & 64.5 & 6.5 & 3.2 & 3.2 \\
\hline Because of one member dominate the participation & 29.0 & 22.6 & 9.7 & 25.8 & 12.9 \\
\hline Because of lack of educational material(s) and other resources & 16.1 & 32.3 & 3.2 & 41.9 & 6.5 \\
\hline $\begin{array}{l}\text { The communication language during your discussion being in } \\
\text { English/language barrier }\end{array}$ & 6.5 & 22.6 & 6.5 & 41.9 & 22.6 \\
\hline Being dependent on few respondents during discussion & 16.1 & 32.3 & 9.7 & 32.3 & 9.7 \\
\hline
\end{tabular}

\subsection{Analysis of Data Obtained Through Focus Group Discussion}

Focus group discussion conducted with $1^{\text {st }}$ year, $2^{\text {nd }}$ year and $3^{\text {rd }}$ year female Biology students; we have identified the following major challenges that hinder successful participation of female in cooperative learning.

1. Lack of awareness about the advantage of cooperative learning

2. Problem of organization or group structuring 
3. Lack of continuous support from the instructors

4. Lack of materials to conduct project and different assignment

5. Some student develop dependency on higher achiever students

6. Shouldering all the responsibility up on group leader

7. Problem of providing different responsibility to group members

8. Absence of rotating the responsibility and re-organizing the group

Based on these findings the researchers proposed different actions to be taken in order to improve the participation of female students in general and their academic achievement in particular under the next section. The possible solutions identified from the practical experience of students were the following:

1. To improve the effectiveness of cooperative learning that promotes female students social interaction, positive interdependence, confidence, self-esteem and achievement.

2. To improve the awareness of all female students about cooperative learning

3. Re-organize students into groups for a particular topic and rotating responsibility.

4. Give clear instructions, and explain how them work together and asses effectively

5. Each member of the group will have a specific task to complete within the group.

6. Assign different tasks like facilitator, note taker, timekeeper, leader, observer, reporter or tasks specific to the topic.

7. The group is responsible for the outcomes, which are evaluating against agreed criteria.

8. Provide material and academicals support to the student to improve their self-esteem and confidence to reduce dependence.

\section{Conclusion and Recommendations}

\subsection{Conclusion}

Based on the research finding the following conclusions were made.

1. It is possible to conclude that group work is implemented by nearly all instructors in a fair level of frequency.

2. Female students' perception towards benefits of group work was positive since learners preferred group assignment than individual assignment and classroom tests.

3. However, students had misconception on objectives of group work, and they perceived group work as a means of getting pass mark than seeing it as a means of learning cooperatively through activity. Therefore, students were blamed for asking mark without achieving task objectives. Students also reported that although group assignment was sometimes done by one student, equal grade were obtained by all members.

4. The students' perception towards difficulties of group work such as unfairness of group grade, making them busy, adding burden work on them, and difficulties to get together outside their classes could affect the participation.

5. Regarding hindrance factors, learners' poor back ground knowledge of content, lack of experiences and skills in time and team work management, in searching, evaluating, and organizing evidences from various sources were reflected. Lastly, these factors were seen as causes for learners' lack of interest to accept responsibility of learning.

6. Therefore, they could develop low self-esteem, low confidence, feel of fear, and sense of depending on dominant learners.

\subsection{Recommendations}

Based on the above conclusion, the following Recommendations were forwarded:

1. The students, included in this study seem to lack awareness on outcome of cooperative working; hence they reflected the objective of group assignment as a means of achieving pass mark instead of constructivist view, building knowledge from group interaction cooperatively. Thus the teachers need to increase the students' awareness of group work outcome and to encourage learners to take responsibility for their own learning.

2. It would be advisable for teachers to assess every member's involvement of team work using crosscheck approach rather than giving equal mark to group. As a result, each student could feel sense of responsibility and might develop habit of learning form team work.

3. Teachers also should give learners clear instructions of work, appropriate level of activities and share of roles and supportive input including references and sources of information.

\section{Acknowledgements}

The authors would like to thank the Bule Hora University, College of Natural and computational Science, Biology Department to give this chance to work during on this area during the training of HDP on teaching learning methods. Next, we would thank all the Female respondents of Biology Department for their willingness to provide the information in group work.

\section{References}

[1] Holter, N. C. (1995). Team assignments can be effective cooperative learning techniques. Journal of Education for Business, vol. 70 (2): 73-76. 
[2] Porter, J. Y. (2006) Using learning communities to enhance counseling curriculum', Vistas Online Available from: http://counselingoutfitters.com/Porter.htm.

[3] Slavin, R. E. (1996). Education for all: Contexts of learning. Lisse, The Netherlands: Swets \& Zeitlinger.

[4] Schofield, M. (2006). Constructivist principles for empowering higher education learning, paperpresented at an international conference: Extending Our Boundaries: New Solutions for Complex Problems in Higher Education July 3-6, 2006, Dunedin, New Zealand. Available from: http://www.iutconference.org/pdfs/SchofieldIIIA1.pdf

[5] Gupta, M. (2004). Enhancing student learning performance through cooperative learning in physics' Assessment and Evaluation in Higher Education. vol. 29 (1): 63-73.

[6] Mugny, G., \& Doise, W. (1978). Socio-cognitive conflict and the structure of individual and collective performances. European Journal of Social Psychology, 8, 181-192.

[7] Vygotsky, L. S. (1978). Mind in society: The development of higher psychological processes. Cambridge, MA: Harvard University Press.

[8] Mohammed Kedir. (2014). Cooperative Learning Practices in College of Education and Behavioral Sciences in Haramaya University, Ethiopia. International Journal of Science and Research, 3 (11).
[9] Gillies, R. (2003). The behaviors, interactions, and perceptions of junior high school students during small group learning. Journal of Educational Psychology, 95, 137-147.

[10] Johnson, D. W., \& Johnson, R. T. (1992). Implementing cooperative learning. Contemporary there is no age bar for Education, 63 (3), 173-181.

[11] Cross, P. (1998). Why learning communities? Why now?About Campus, July-August 1998.

[12] Gross, B. (1993). Tools for Teaching. Jossey-Bass Publisher, San Francisco.

[13] Weimer, M. (2008). Active learning advocates and lectures. Retrieved from: http://teachingprofessor.blogspot.com/2008/06/activelearningadvocates-andlectures.

[14] Menges, R. J. and Weimer, M. (1996). Teaching on solid ground: Using scholarship to improve practice. San Francisco, CA: Jossey-Bass Inc.

[15] Jolliffe, W. (2007). Cooperative learning in the class room: putting in to practice. New Delhi: SAGE Publications India Pvt Ltd.

[16] Burdett, J. (2003). Making groups work: university students 'perceptions', International Education Journal, vol. 4 (3): 177-191. 